\title{
Quantifying nitrous oxide emissions from Chinese grasslands with a process-based model
}

\author{
F. Zhang ${ }^{1,2}$, J. Qi ${ }^{2,1}$, F. M. Li ${ }^{1}$, C. S. $\mathbf{L i}^{3}$, and C. B. $\mathbf{L i}^{2,4}$ \\ ${ }^{1}$ Key Laboratory of Arid and Grassland Agro-Ecology (MOE), Lanzhou University, Lanzhou, Gansu, 730000, China \\ ${ }^{2}$ Center for Global Change and Earth Observations, Michigan State University, East Lansing, MI, 48823, USA \\ ${ }^{3}$ Institute for the Study of Earth, Oceans, and Space, University of New Hampshire, Durham, NH 03824, USA \\ ${ }^{4}$ Key Laboratory of Western China's Environmental Systems (MOE), Lanzhou University, Lanzhou, Gansu, 730000, China
}

Received: 2 January 2010 - Published in Biogeosciences Discuss.: 5 March 2010

Revised: 28 May 2010 - Accepted: 31 May 2010 - Published: 28 June 2010

\begin{abstract}
As one of the largest land cover types, grassland can potentially play an important role in the ecosystem services of natural resources in China. Nitrous oxide $\left(\mathrm{N}_{2} \mathrm{O}\right)$ is a major greenhouse gas emitted from grasslands. Current $\mathrm{N}_{2} \mathrm{O}$ inventory at a regional or national level in China relies on the emission factor method, which is based on limited measurements. To improve the accuracy of the inventory by capturing the spatial variability of $\mathrm{N}_{2} \mathrm{O}$ emissions under the diverse climate, soil and management conditions across China, we adopted an approach by utilizing a process-based biogeochemical model, DeNitrification-DeComposition (DNDC), to quantify $\mathrm{N}_{2} \mathrm{O}$ emissions from Chinese grasslands. In the present study, DNDC was tested against datasets of $\mathrm{N}_{2} \mathrm{O}$ fluxes measured at eight grassland sites in China with encouraging results. The validated DNDC was then linked to a GIS database holding spatially differentiated information of climate, soil, vegetation and management at county-level for all the grasslands in the country. Daily weather data for 20002007 from 670 meteorological stations across the entire domain were employed to serve the simulations. The modelled results on a national scale showed a clear geographic pattern of $\mathrm{N}_{2} \mathrm{O}$ emissions. A high-emission strip showed up stretching from northeast to central China, which is consistent with the eastern boundary between the temperate grassland region and the major agricultural regions of China. The grasslands in the western mountain regions, however, emitted much less $\mathrm{N}_{2} \mathrm{O}$. The regionally averaged rates of $\mathrm{N}_{2} \mathrm{O}$ emissions were $0.26,0.14$ and $0.38 \mathrm{~kg}$ nitrogen $(\mathrm{N}) \mathrm{ha}^{-1} \mathrm{y}^{-1}$ for
\end{abstract}

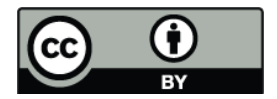

Correspondence to: $\mathrm{F} . \mathrm{M}$. Li (fmli@lzu.edu.cn) the temperate, montane and tropical/subtropical grasslands, respectively. The annual mean $\mathrm{N}_{2} \mathrm{O}$ emission from the total 337 million ha of grasslands in China was $76.5 \pm 12.8 \mathrm{Gg} \mathrm{N}$ for the simulated years.

\section{Introduction}

According to the Intergovernmental Panel on Climate Change (IPCC), the global average surface temperature has increased by around $0.74 \pm 0.18^{\circ} \mathrm{C}$ during the 20th century, and global atmospheric concentrations of greenhouse gases (GHGs) have increased markedly as a result of human activities since 1750 (IPCC, 2007). The increased GHG emissions have altered the energy balance of the climate system (IPCC, 2007). On a global scale, carbon dioxide $\left(\mathrm{CO}_{2}\right)$, methane $\left(\mathrm{CH}_{4}\right)$ and nitrous oxide $\left(\mathrm{N}_{2} \mathrm{O}\right)$, contribute 76.7 , 14.3 and $7.9 \%$, respectively, to the anthropogenic GHGs' effect (IPCC, 2007). The instantaneous flux rates of the GHGs were an important clue for assessing the terrestrial ecosystem contributions to climate change (Du et al., 2008). Among the three GHGs, $\mathrm{N}_{2} \mathrm{O}$ possesses the longest atmospheric lifetime and highest radiative forcing potential (Cicerone, 1989; Mummey et al., 2000; IPCC, 2007). However, due to the difficulties in monitoring the gas fluxes at a regional scale, large uncertainty exists on the global $\mathrm{N}_{2} \mathrm{O}$ budget (Bouwman et al., 2000; Chapuis-Lardy et al., 2007). Grasslands, where herbaceous plants form the dominant climax community (Coupland, 1992; Mummey et al., 2000), play a significant role in the regional climate and global carbon cycle both in tropical and temperate regions (Scurlock and Hall, 1998). However, compared with forest ecosystems, there have been

Published by Copernicus Publications on behalf of the European Geosciences Union. 
fewer studies on $\mathrm{N}_{2} \mathrm{O}$ exchange in grassland ecosystems, despite the fact that grassland covers about one-fifth of the world's land surface and about $40 \%$ of China's national land cover (Allard et al., 2007; Kang et al., 2007). It is important, therefore, to quantify $\mathrm{N}_{2} \mathrm{O}$ emissions from grasslands for a more accurate assessment of the $\mathrm{N}_{2} \mathrm{O}$ budget (Mummey et al., 2000) and to gain a better understanding of the potential $\mathrm{N}_{2} \mathrm{O}$ production and emission processes in grassland ecosystems for future climate change mitigation (Guo and Zhou, 2007).

The IPCC method was used to estimate $\mathrm{N}_{2} \mathrm{O}$ emissions on a national scale in Initial National Communication on Climate Change by the People's Republic of China in 2004. However, it is less capable of quantifying impacts of climate or the management of the gas fluxes. Consequently processoriented models were proposed to improve $\mathrm{N}_{2} \mathrm{O}$ emission estimates (Boeckx and Van Cleemput, 2001). On a national scale, process-based models have proven useful in reducing uncertainty and helping to understand the complex biogeochemical processes involved in trace gas production (Barnsley, 2007). The Chinese government reported agricultural $\mathrm{N}_{2} \mathrm{O}$ emissions in the 1990s using IPCC methods, but cited a deficit of emissions data specific to grasslands in the report (China, 2004). Li et al. (2001) compared the IPCC method and the DNDC model in the evaluation of Chinese agricultural $\mathrm{N}_{2} \mathrm{O}$ emissions and found that the process-based DNDC model and the strictly empirical IPCC methodology gave similar estimates of direct $\mathrm{N}_{2} \mathrm{O}$ emissions from cropland soils in 1990. However, DNDC provided the spatial pattern of $\mathrm{N}_{2} \mathrm{O}$ emissions on a national scale (Li et al., 2001).

Grassland is widely distributed in north and northwest China (Kang et al., 2007), and is under threat of serious degradation and over grazing. Researchers have advocated alternative grassland management practices including intensive management (Nan, 2005). Grassland management practices have recently undergone some significant changes in China due to the economic development over the past decades (Chen and Chen, 2007). To slow down the degradation to maintain sustainability of the grasslands, regulations with new management practices have been introduced by the Chinese central government (Chen and Chen, 2007; Unkovich and Nan, 2008). These include converting reclaimed land to pasture lands, practicing rotational grazing methods using fencing; promoting conservation practices; tending and controlling rodents and insect pests; promoting rangeland improvements such as shallow-ploughing, fertilization and irrigation; and promoting restoration by aerialsowing, cultivation practices, converting cultivated lands to pastures, and the establishment of a forage base (Yang, 1992; Chen and Chen, 2007). Among of these practices, fertilization and improved grazing management practices are highly recommended (Conant et al., 2001). These management options potentially alter $\mathrm{N}_{2} \mathrm{O}$ emissions and, hence, change the national inventory of $\mathrm{N}_{2} \mathrm{O}$. Some preliminary researches indicated that the magnitudes of $\mathrm{N}_{2} \mathrm{O}$ fluxes from Chinese grassland vary greatly in space and time (Du et al., 1997, 2006; Dong et al., 2000; Xu et al., 2003). There is a need to use process-based models to achieve a more accurate estimate of the $\mathrm{N}_{2} \mathrm{O}$ emissions on a national level in consideration of the dynamics of grassland management. This paper reports the first attempt to quantify $\mathrm{N}_{2} \mathrm{O}$ emissions from Chinese grasslands with a process-based model. To approach this goal, we adopted a four-phase method that included (1) database development, (2) scaling up, (3) model validation, and (4) sensitivity analysis.

\section{Method}

\subsection{Database development}

To apply DNDC on a national scale, we developed a GIS database to store the spatially distributed information of climate, soil and grassland types. Counties were used as the basic unit for the simulation. The database contained 2368 counties, excluding those with small areas less than $500 \mathrm{~km}^{2}$. The database consisted of: (1) 18 grassland types with plant properties (e.g. maximal production, maximal height, and root/shoot ratio); (2) soil properties (e.g. maximum and minimum soil organic carbon(SOC) content, bulk density, clay fraction and $\mathrm{pH}$ ); (3) daily climate data (e.g. maximum and minimum air temperatures and precipitation); and (4) areas and geographic locations of grassland types at county level. These data were obtained from the Commission for the Integrated Survey of Natural Resources; the Institute of Soil Science, Chinese Academy of Sciences and the Chinese Meteorological Administration.

\subsubsection{Grassland dataset}

There is a large uncertainty concerning the total grassland area in China. Fang et al. (1996) estimated 569.9 million ha based on agricultural atlases and land use maps of the 1980s. Ni (2001) used 405.9 million ha in his report, and Fan et al. (2008) estimated 331 million ha of grassland area. Because of the large discrepancies, in this study, we digitized the 1:1000 000 grassland resource maps (Commission for Integrated Survey of Natural Resources, 1995), and classified all grasslands into 18 vegetation types, according to $\mathrm{Ni}$ (2002). Considering the extensive changes in land use over the last decade in China (Lin and Ho, 2003), we applied the 1:100,000 National Land Cover Dataset (NLCD) of China acquired in 1999 and 2000 to modify the grassland area by retaining only those areas identified as grassland in the NLCD. The final grassland area of our new database was 336.98 million ha and the database had $10 \mathrm{~km}$-resolution (Fig. 1). 


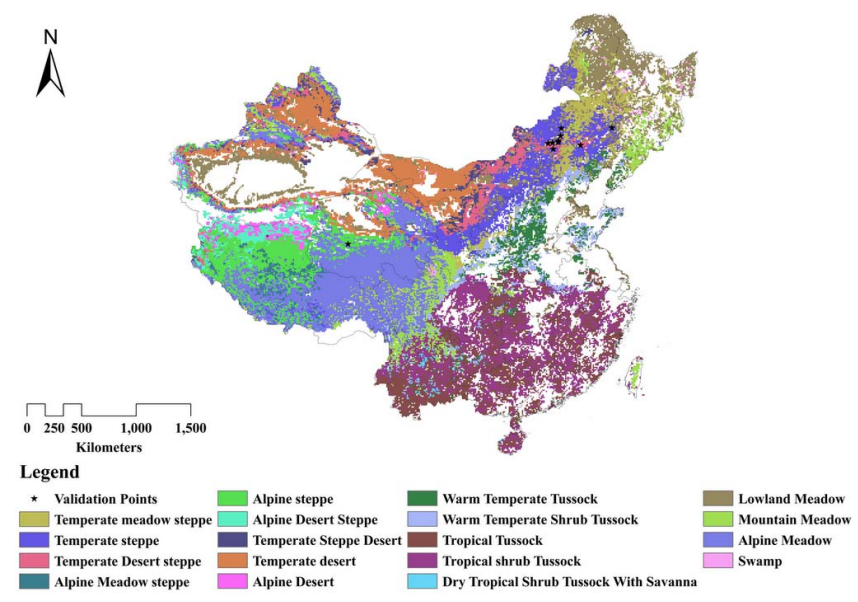

Fig. 1. China's 18 types grassland distributions, five-pointed stars are model validation points.

\subsubsection{Soil dataset}

We used a 1:1000000 scale soil database developed by the Institute of Soil Science, Chinese Academy of Sciences, which was compiled based on the second national soil survey conducted in 1979-1994 covering all the counties (National Soil Survey Office, 1993, 1994a, b, 1995a, b, 1996). The database contains three attributes: locations, attributes and reference systems. It contains multi-layer soil properties (e.g. organic matter, $\mathrm{pH}$ and bulk density), soil texture (sand, silt and clay proportions) and spatial information (Shi et al., 2004; Yu et al., 2007), which were used in model simulation. In this study, we used data in the upper 0-10-cm soil profile as the soil surface properties for model simulations and for data assimilation; it was resampled to $10 \mathrm{~km}$-resolution.

\subsubsection{Climate dataset}

We used the $10 \mathrm{~km}$-resolution daily national climate data from 2000-2007, which were interpolated from 670 meteorological stations using the Ordinary Kriging method. The climate data included daily precipitation, maximum and minimum temperatures (http://data.cma.gov.cn/).

\subsubsection{Grazing data}

There are deficiencies in the county-scale statistical data for grazing stock and great heterogeneity in the grassland management regimes in China. Based on the statistical data of 2000 at the national scale from the National Bureau of Statistics of China (NBSC, http://www.stats.gov.cn/english/ statisticaldata/), we assumed that the grasslands in China experienced a similar grazing practice, and that livestock were evenly distributed among all grasslands. The average national grazing stock value was applied (total livestock divided by total area). Specifically, the grazing stocks were
0.32, 0.06 and 0.72 head ha $^{-1}$ of cattle, horses and sheep, respectively, and no fertilizer application was assumed.

\subsection{Model upscaling}

To estimate the national $\mathrm{N}_{2} \mathrm{O}$ emissions from grasslands in China we linked DNDC to the database containing climate data (2000-2007), soil properties and grassland types and total grassland area. Because SOC content was one of the most sensitive factors affecting $\mathrm{N}_{2} \mathrm{O}$ fluxes (Fig. $3 \mathrm{c}$ ), we ran the DNDC model for each grid-cell with the maximum and minimum SOC content values to quantify the uncertainty in the upscaling (see details in $\mathrm{Li}, 2007$ ).

\subsection{Model validation}

DNDC is a process-based model of carbon and nitrogen biogeochemistry for terrestrial ecosystems. The model was originally developed for estimating $\mathrm{N}_{2} \mathrm{O}$ emissions from agricultural ecosystems (Li, 1992a, b; Li et al., 2004). Detailed processes of nitrification and denitrification were built in the model to track the kinetic processes of $\mathrm{N}_{2} \mathrm{O}$ production and consumption driven by the soil climate and substrate concentrations ( $\mathrm{Li}, 2007)$. DNDC consists of two main components. The first component consists of soil climate, crop growth and decomposition sub-models converts primary drivers such as climate, soil, vegetation and human activities into soil environmental factors (e.g. soil temperature, humidity, $\mathrm{pH}$, redox potential and substrate concentration gradients). The second component of DNDC includes nitrification, denitrification and fermentation sub-models calculates $\mathrm{N}_{2} \mathrm{O}$ and $\mathrm{CH}_{4}$ production and consumption ( $\mathrm{Li}, 2000$; $\mathrm{Li}$ et al., 2000). The DNDC model has been successfully tested and applied for $\mathrm{N}_{2} \mathrm{O}$ inventory in many countries across climatic zones, soil types and management regimes (Frolking et al., 1998; Li, 2000; Li et al., 2000, 2001, 2005; Saggar et al., 2004; Beheydt et al., 2007; Saggar et al., 2007), and is recognized as one of the most widely used $\mathrm{N}_{2} \mathrm{O}$ models in the world (Chen et al., 2008). DNDC has also been applied in China for estimating $\mathrm{N}_{2} \mathrm{O}$ emissions from grassland at the site-scale (Xu et al., 2003).

We further tested DNDC for its applicability to grasslands in China. Eight grassland sites use the same management practices as in the DNDC simulation, where $\mathrm{N}_{2} \mathrm{O}$ fluxes were measured and the annual emission rates were reported in publications (Fig. 1) were used for validation tests. The sites were natural grasslands as defined by Coupland (1992) without any fertilizer and grazing applied. The modelled nongrazing annual $\mathrm{N}_{2} \mathrm{O}$ emissions rates were consistent with reports for the sites (Fig. 2), Regression analysis demonstrated that the simulated emissions explained $64 \%$ of the variation in observed emissions. The intercept is significantly different from 0 at the 0.05 alpha level. For all experiments presented in Table 1, the RMSE is equal to $0.87 \mathrm{~kg} \mathrm{Nha}^{-1}$ year $^{-1}$, the $\mathrm{EF}$ is positive, and $\mathrm{CD}$ is greater than 1 (Table 1 ). 
Table 1. Selected statistics for comparison of observed and simulated $\mathrm{N}_{2} \mathrm{O}$ emissions $\left(\mathrm{kg} \mathrm{Nha}^{-1}\right.$ year $\left.^{-1}\right)$.

\begin{tabular}{llll}
\hline Data source & RMSE & EF & CD \\
\hline References points & 0.87 & 0.75 & 3.97 \\
\hline
\end{tabular}

RMSE: the root mean squared error; EF: the coefficient of model efficiency; CD: the coefficient of model determination (Smith et al., 1997)

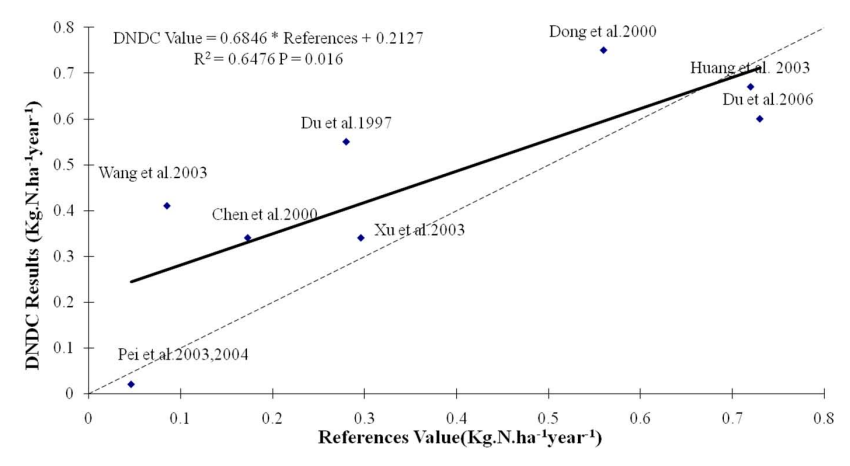

Fig. 2. DNDC results compared with literature reports. Dashed line is $1: 1$ line.

\subsection{Sensitivity analysis}

The sensitivity analysis was conducted by varying a single model input parameter in a predefined range, which was commonly observed in a unit of study, while keeping all other input parameters constant. Simulated annual $\mathrm{N}_{2} \mathrm{O}$ flux sensitivities were evaluated for soil factors (i.e. $\mathrm{pH}$, soil texture and SOC content), grazing intensity, and climate (i.e. precipitation and temperature). The baseline simulation was done using the average values of the entire grassland region (Table 2). The sensitivity tests were done to assess the model responses to soil attributes, management options, and climate variables.

\section{Results and discussion:}

\subsection{Model sensitivities to environmental variables}

Table 2 lists the parameters in the sensitivity analysis. It is clear that the model responded to changes in both environmental factors as well as to human management options. This is the basis where the model can be used to assess how climate change and human management practices affect $\mathrm{N}_{2} \mathrm{O}$ emissions from the vast grasslands in China.

\section{Sensitivity to soil attributes}

The modelled $\mathrm{N}_{2} \mathrm{O}$ emission rates correlated well with the initial SOC contents (Fig. 3c), that is in agreement with the observations made by other researchers (e.g., Babu et al.,
Table 2. Baseline values for sensitivity tests.

\begin{tabular}{|c|c|c|}
\hline Property & Baseline value & Range tested \\
\hline Annual mean temperature $\left({ }^{\circ} \mathrm{C}\right)$ & 9 & $7-11$ \\
\hline Total annual precipitation $(\mathrm{mm})$ & 520 & $416-624$ \\
\hline Clay fraction $(\%)$ & 0.19 & $0.03-0.63$ \\
\hline Field capacity (\%) & 0.49 & Not varied \\
\hline Wilting point $(\%)$ & 0.22 & Not varied \\
\hline Porosity $(\%)$ & 0.451 & Not varied \\
\hline Initial soil $\mathrm{C}$ fraction $\left(\mathrm{kg} \mathrm{C} \mathrm{kg}^{-1}\right.$ soil) & 0.0025 & $0.005-0.03$ \\
\hline Bulk density $\left(\mathrm{g} \mathrm{cm}^{-3}\right)$ & 1.22 & Not varied \\
\hline Soil pH & 7.4 & 5-9 \\
\hline Number of days grazed $\left(\mathrm{y}^{-1}\right)$ & 12 & Not varied \\
\hline Grazing hours per day & 12 & $0-24$ \\
\hline Cattle grazing intensity (head ha ${ }^{-1}$ ) & 0.3 & Not varied \\
\hline Sheep grazing intensity (head ha ${ }^{-1}$ ) & 3 & 4-7 \\
\hline Fertilizer $\left(\mathrm{Kg} \mathrm{N} \mathrm{ha}^{-1}\right)$ & 0 & $5-45$ \\
\hline
\end{tabular}

2006). Variation of the initial SOC content showed significant effects on production and emission of $\mathrm{N}_{2} \mathrm{O}$. More $\mathrm{N}_{2} \mathrm{O}$ was produced from soils with $\mathrm{pH} 7$ than from alkaline soils (Fig. 3a), however, $\mathrm{pH}$ had a minor effect on $\mathrm{N}_{2} \mathrm{O}$ emissions. Soil texture was also a sensitive factor due to its effects on soil aeration status; sandy loam soil was more likely to produce higher $\mathrm{N}_{2} \mathrm{O}$ than clay soil (Fig. 3b).

\section{Sensitivity to management options}

The modelled $\mathrm{N}_{2} \mathrm{O}$ emission was very sensitive to grazing management options, such as grazing intensity and duration. Enhanced grazing intensity increased $\mathrm{N}_{2} \mathrm{O}$ emissions (Fig. 3d, e). The result was in agreement with that reported by Flechard et al. (2007). Nitrogen deficit is one of the major factors limiting grass growth in most Chinese grasslands (Nan, 2005; Unkovich and Nan, 2008). When fertilizer application rates increased from 0 to $45 \mathrm{~kg} \mathrm{Nha}^{-1} \mathrm{y}^{-1}, \mathrm{~N}_{2} \mathrm{O}$ emissions increased from 0.1 to $0.25 \mathrm{~kg} \mathrm{~N} \mathrm{ha}^{-1} \mathrm{y}^{-1}$ (Fig. 3f). This suggested that the fertilized grassland could increase $\mathrm{N}_{2} \mathrm{O}$ emission greatly.

\section{Sensitivity to climate conditions}

The $\mathrm{N}_{2} \mathrm{O}$ emissions were susceptible to changes in rainfall and temperature, which is in agreement with previous studies that show that $\mathrm{N}_{2} \mathrm{O}$ emissions were positively correlated with air or soil temperature (Yamulki et al., 1997; Dong et al., 2000). In the present study, precipitation was either increased or decreased by $20 \%$ of the baseline value $\left(520 \mathrm{~mm} \mathrm{y}^{-1}\right)$. Increases in precipitation elevated $\mathrm{N}_{2} \mathrm{O}$ emissions (Fig. 3g). Modelled data showed that the high precipitation stimulated denitrification, which is a major process producing $\mathrm{N}_{2} \mathrm{O}$ in DNDC. Denitrification occurs under anaerobic conditions in soils with high moisture content, so we would expect $\mathrm{N}_{2} \mathrm{O}$ emissions to increase with precipitation. The effect of temperature was examined by running a sequence of simulations with daily temperatures varied by a 1 or $2{ }^{\circ} \mathrm{C}$ increment; $\mathrm{N}_{2} \mathrm{O}$ emissions did not follow a simple relationship with change in temperature. With an increase of $1{ }^{\circ} \mathrm{C}$ in daily temperature, the $\mathrm{N}_{2} \mathrm{O}$ emissions changed 


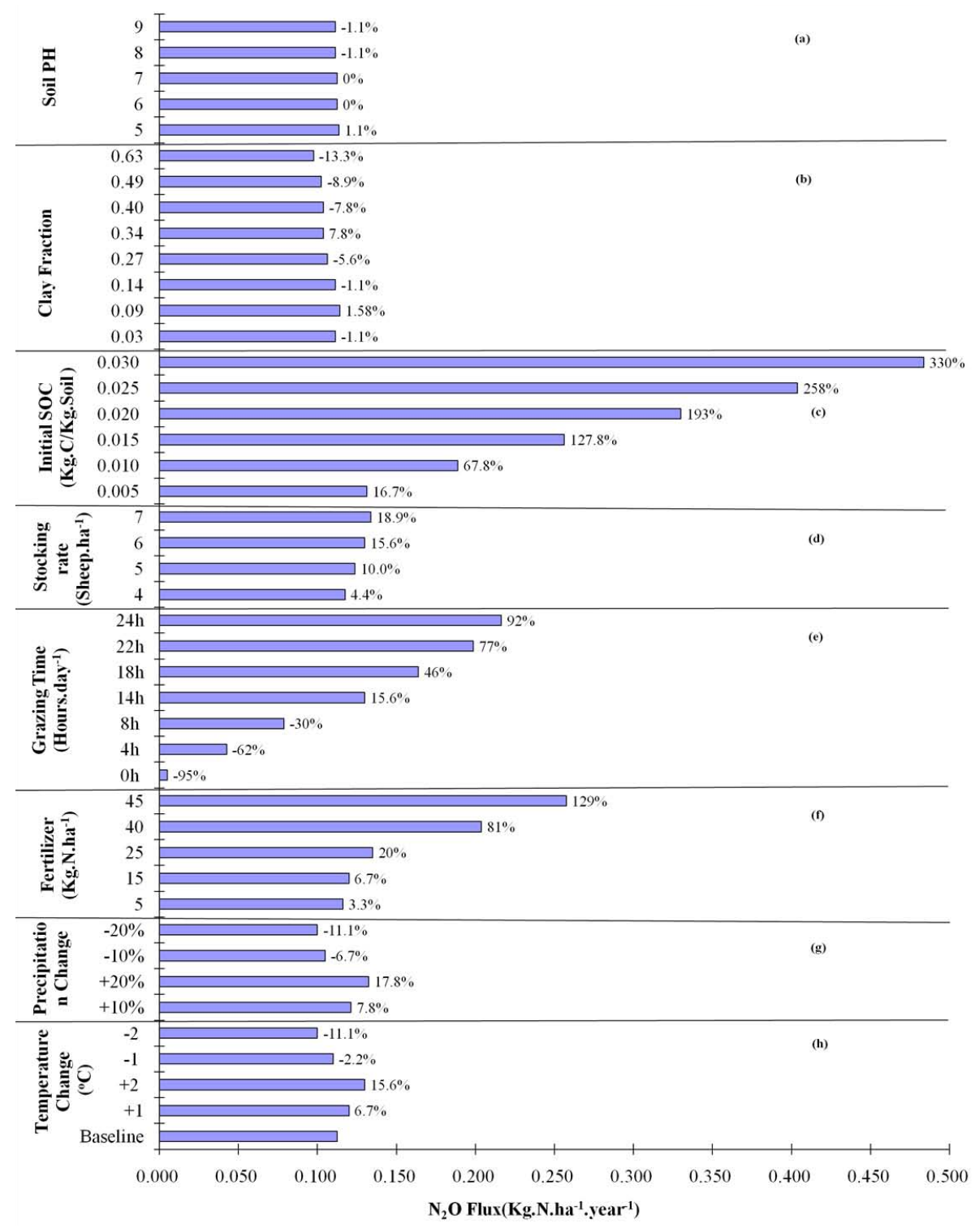

Fig. 3. Effect of changing a single factor of soil, management and climate on sensitivity analysis scenario.

slightly; but when the increase was $2{ }^{\circ} \mathrm{C}$, the total $\mathrm{N}_{2} \mathrm{O}$ emissions changed significantly (Fig. $3 \mathrm{~h}$ ). When temperature decreased, $\mathrm{N}_{2} \mathrm{O}$ emissions also clearly decreased, since a decrease in temperature decreased the rate of organic matter decomposition and, therefore, decreased nitrification, which is an important source of $\mathrm{N}_{2} \mathrm{O}$ ( $\mathrm{Li}$ et al., 2000).

\subsection{National inventory of $\mathrm{N}_{2} \mathrm{O}$ emissions from China's grasslands}

Based on the modelled annual $\mathrm{N}_{2} \mathrm{O}$-fluxes for the eight years (Table 3), a multi-year average $\mathrm{N}_{2} \mathrm{O}$ emission value was calculated for each grid-cell as well as for all grasslands in China. The mean annual $\mathrm{N}_{2} \mathrm{O}$ emission rates from all the grasslands were $<0.5 \mathrm{~kg} \mathrm{Nha}^{-1} \mathrm{y}^{-1}$ with the highest for swamp grassland and the lowest for Alpine desert grassland (0.48 and $0.02 \mathrm{~kg} \mathrm{Nha}^{-1} \mathrm{y}^{-1}$, respectively) and the national average $0.22 \mathrm{~kg} \mathrm{Nha}^{-1} \mathrm{y}^{-1}$. National inventory of $\mathrm{N}_{2} \mathrm{O}$ emissions from Chinese grassland was calculated based on the area and $\mathrm{N}_{2} \mathrm{O}$ emission rates for each type of grassland (Table 3). The results showed that the 337 million ha of grasslands in China emitted $76.5 \pm 12.8 \mathrm{Gg} \mathrm{N}_{2} \mathrm{O}-\mathrm{N} \mathrm{y}^{-1}$ on a multi-year average basis.

The modelled $\mathrm{N}_{2} \mathrm{O}$ fluxes were analysed by combining the 18 types of grassland into three categories based on ecological climate zones (China Meteorological Administration, 2002). The three categories were temperate, montane and tropical/subtropical grasslands (Table 4, Fig. 4). Each of the three categories possessed specific environmental features and was basically consistent with climate patterns. The 


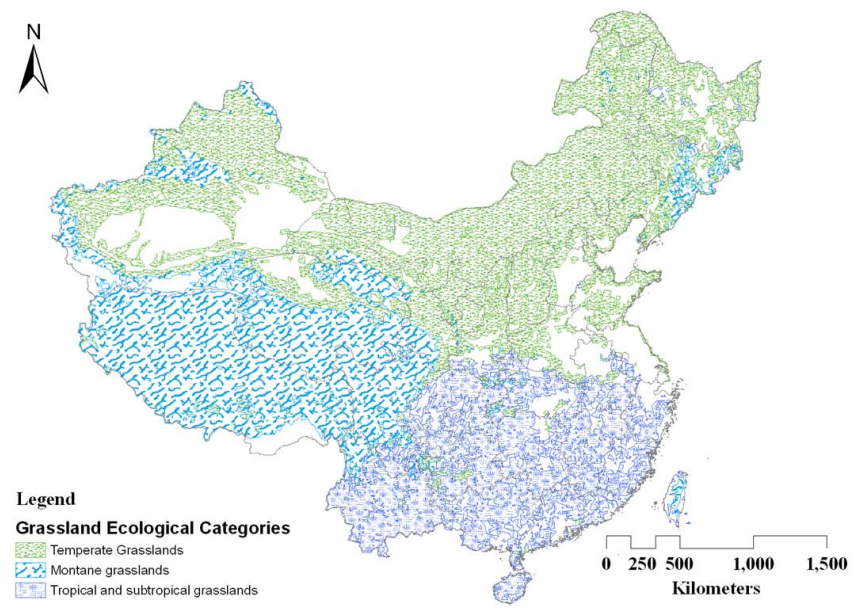

Fig. 4. Three grassland ecological categories of Chinese grasslands.

greatest $\mathrm{N}_{2} \mathrm{O}$ flux $\left(0.38 \mathrm{~kg} \mathrm{Nha}^{-1} \mathrm{y}^{-1}\right)$ occurred in the tropi$\mathrm{cal} /$ subtropical grassland region, in which both moisture and temperature were more favourable for $\mathrm{N}_{2} \mathrm{O}$ production. In the montane grassland region, the average $\mathrm{N}_{2} \mathrm{O}$ flux was the lowest at $0.14 \mathrm{~kg} \mathrm{Nha}^{-1} \mathrm{y}^{-1}$; this region is humid but with low temperature. The temperate grassland region had a medium emission flux, averaging $0.26 \mathrm{~kg} \mathrm{Nha}^{-1} \mathrm{y}^{-1}$. Even though the temperate grassland's $\mathrm{N}_{2} \mathrm{O}$ flux rate was in the mid-range, it comprised $49 \%$ of the 337 million ha of the total grassland area in China (Table 4) and, thus, this category's contribution is large, accounting for $57 \%$ of national emissions. Despite the large amount of montane grasslands (39\% of the total grassland area in China), due to the lower $\mathrm{N}_{2} \mathrm{O}$ emission rate, it only contributed $24 \%$ of the total $\mathrm{N}_{2} \mathrm{O}$ flux. The tropical/subtropical grasslands occupy only $12 \%$ of total grassland areas, but account for $19 \%$ of the total $\mathrm{N}_{2} \mathrm{O}$ flux.

\subsection{Spatial and temporal distribution of $\mathrm{N}_{2} \mathrm{O}$ emissions}

The spatial distribution of the grassland $\mathrm{N}_{2} \mathrm{O}$ fluxes was basically consistent with the climate patterns. In China, mean annual precipitation and temperature tend to decrease from east to west and from south to north. $\mathrm{N}_{2} \mathrm{O}$ flux rates also followed this climate change trend, gradually decreasing from east to west regions. In the western high-altitude region, the $\mathrm{N}_{2} \mathrm{O}$ flux rates were lower than in the eastern and southern region, especially in eastern Inner Mongolia and the sparsely distributed grasslands of the south, where the $\mathrm{N}_{2} \mathrm{O}$ flux (Fig. 5) was higher.

On the national scale, during 2000-2007 the annual $\mathrm{N}_{2} \mathrm{O}$ emission rate fluctuated year-to-year, and had an increasing trend, but not significantly ( $\mathrm{P}=0.14)$ (Fig. 6). In 2001 and 2005 , the modelled national $\mathrm{N}_{2} \mathrm{O}$ emissions were higher than in other years. In 2005, the total $\mathrm{N}_{2} \mathrm{O}$ had an abrupt emission peak compared with other years. From 2000-2007, climate

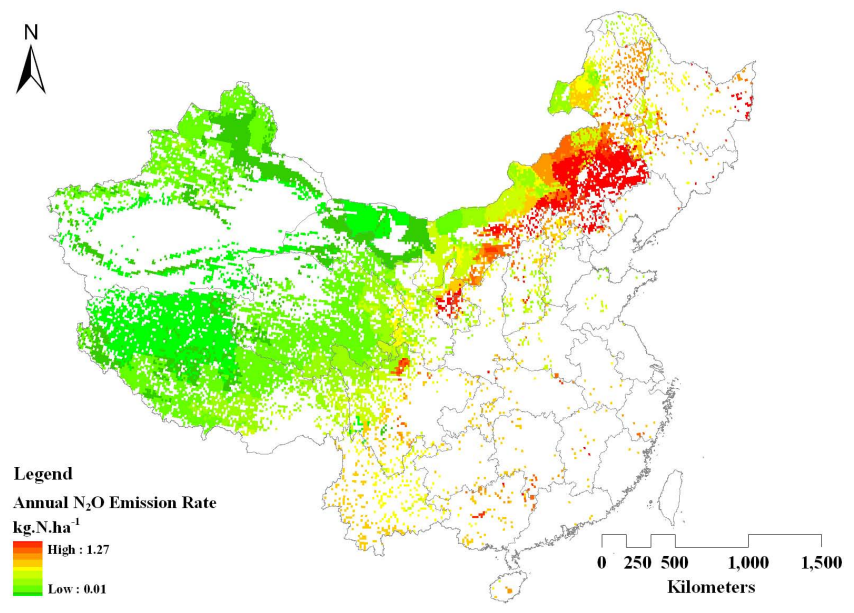

Fig. 5. The spatial distribution of $\mathrm{N}_{2} \mathrm{O}$ flux for Chinese grassland (the blank area is non-grassland).

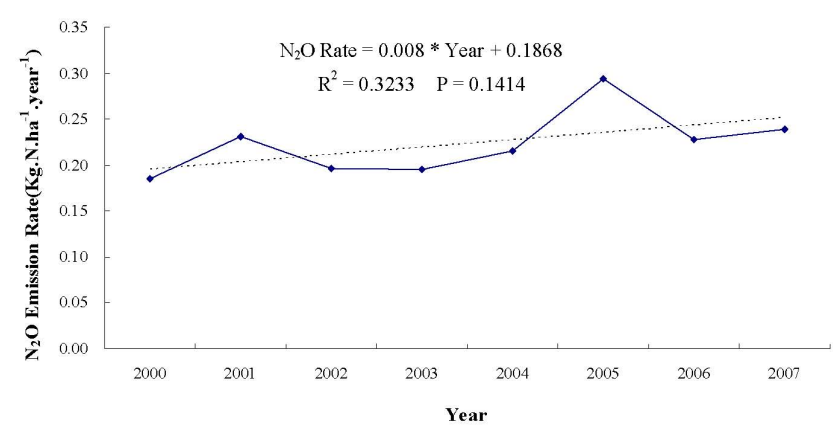

Fig. 6. Chinese grassland $\mathrm{N}_{2} \mathrm{O}$ emission rate yearly changes for 2000-2007.

is the only changed factor in the simulation. We compared the accumulated annual temperature $>0{ }^{\circ} \mathrm{C}$ and the annual accumulated precipitation between 2005 and 2001 (Fig. 7a, b). These comparisons suggested that climate change seems to be the reason for varied $\mathrm{N}_{2} \mathrm{O}$ emissions. In the northern grassland region, the precipitation and the temperature increased (Fig. 7a, b), which is believed to have caused the $\mathrm{N}_{2} \mathrm{O}$ emissions change. As climate could play an important role in $\mathrm{N}_{2} \mathrm{O}$ emissions, further climate change may have some impact on the $\mathrm{N}_{2} \mathrm{O}$ emission pattern. However, more quantified research and long time-scale simulation is needed to verify the relationship between climate and $\mathrm{N}_{2} \mathrm{O}$ emissions.

\subsection{Comparison of $\mathrm{N}_{2} \mathrm{O}$ with worldwide grassland}

In China, most grasslands are located in semi-arid and arid areas, which are classified as ecologically fragile zones (Liu, 2001). The poor soils and low precipitation can limit $\mathrm{N}_{2} \mathrm{O}$ emissions due to the depressed nitrification and denitrification processes. However, some grasslands such as meadow and swamp grasslands have relatively high humidity and the 
Table 3. Modelled average $\mathrm{N}_{2} \mathrm{O}$ emission rates over eight years for 18 types of grassland in China $\left(\mathrm{kg} \mathrm{Nha}^{-1} \mathrm{y}^{-1}\right)$, grassland area and total $\mathrm{N}_{2} \mathrm{O}$ emission per year.

\begin{tabular}{lccc}
\hline Grassland Type & $\begin{array}{c}\text { Emission rates } \\
(\mathrm{kg} \mathrm{Nha}-1 \mathrm{y}-1)\end{array}$ & $\begin{array}{c}\text { Grassland area } \\
(\text { million ha })\end{array}$ & $\begin{array}{c}\text { Total N } \mathrm{N}_{2} \text { emission } \\
(\mathrm{Gg} \mathrm{Ny}-1)\end{array}$ \\
\hline Temperate Meadow Steppe (TMS) & 0.26 & 18 & 4.7 \\
Temperate Steppe (TS) & 0.33 & 47 & 15.5 \\
Temperate Desert Steppe (TDS) & 0.16 & 16 & 2.6 \\
Alpine Meadow Steppe (AMS) & 0.10 & 5 & 0.5 \\
Alpine Steppe (AS) & 0.08 & 30 & 2.4 \\
Alpine Desert Steppe (ADS) & 0.03 & 6 & 0.2 \\
Temperate Steppe Desert (TSD) & 0.11 & 7 & 1.8 \\
Temperate Desert (TD) & 0.09 & 20 & 0.2 \\
Alpine Desert (AD) & 0.03 & 5 & 3.1 \\
Warm Temperate Tussock (WTT) & 0.28 & 11 & 3.6 \\
Warm Temperate Shrub Tussock (WTST) & 0.30 & 12 & 7 \\
Tropical Tussock (TT) & 0.37 & 19 & 6.3 \\
Tropical Shrub Tussock (TST) & 0.37 & 17 & 0.3 \\
Dry Tropical Shrub Tussock with Savanna (DTSTS) & 0.32 & 1 & 11.2 \\
Lowland Meadow (LM) & 0.32 & 35 & 5.1 \\
Mountain Meadow (MM) & 0.23 & 22 & 10.2 \\
Alpine Meadow (AM) & 0.16 & 64 & 1 \\
Swamp & 0.48 & 2 & $76.5 \pm 12.8$ \\
Average rate/Total area/Total emission & 0.22 & 337 & \\
\hline
\end{tabular}

Table 4. Grassland categories, zonal climate and average $\mathrm{N}_{2} \mathrm{O}$ flux. The weighted emission rates were calculated by category total emission 736 divided by category total area.

\begin{tabular}{|c|c|c|c|c|c|c|}
\hline Categories & $\begin{array}{l}\text { Grassland } \\
\text { Type }\end{array}$ & $\begin{array}{l}\text { Annual } \\
\text { Precipitation } \\
(\mathrm{mm})\end{array}$ & $\begin{array}{l}\text { Annual } \\
\text { Temperature } \\
\left({ }^{\circ} \mathrm{C}\right)\end{array}$ & $\begin{array}{l}\text { Area } \\
\text { (million } \\
\text { ha) } \\
{[\%]}\end{array}$ & $\begin{array}{l}\text { Weighted } \mathrm{N}_{2} \mathrm{O} \\
\text { Emission Rate } \\
\left(\mathrm{kg} \mathrm{Nha}^{-1} \mathrm{y}^{-1}\right)\end{array}$ & $\begin{array}{l}\text { Total } \mathrm{N}_{2} \mathrm{O} \text { Emission } \\
\left(\mathrm{Gg} \mathrm{Ny}^{-1}\right)[\%]\end{array}$ \\
\hline $\begin{array}{l}\text { Temperate } \\
\text { Grassland }\end{array}$ & $\begin{array}{l}\text { TMS } \\
\text { TS } \\
\text { TDS } \\
\text { TSD } \\
\text { TD } \\
\text { WTT } \\
\text { WTST } \\
\text { LM }\end{array}$ & 282.11 & 5.54 & $\begin{array}{l}165.92 \\
{[49]}\end{array}$ & 0.26 & $\begin{array}{l}43.3 \\
{[57]}\end{array}$ \\
\hline $\begin{array}{l}\text { Montane } \\
\text { grasslands }\end{array}$ & $\begin{array}{l}\text { AMS } \\
\text { AS } \\
\text { ADS } \\
\text { AD } \\
\text { AM } \\
\text { MM }\end{array}$ & 400.77 & -1.25 & $\begin{array}{l}132.56 \\
{[39]}\end{array}$ & 0.14 & $\begin{array}{l}18.6 \\
{[24]}\end{array}$ \\
\hline $\begin{array}{l}\text { Tropical/ } \\
\text { subtropical } \\
\text { grasslands }\end{array}$ & $\begin{array}{l}\text { TT } \\
\text { TST } \\
\text { DTSTS } \\
\text { Swamp }\end{array}$ & 1109.49 & 16.22 & $\begin{array}{l}39.50 \\
{[12]}\end{array}$ & 0.38 & $\begin{array}{l}14.6 \\
{[19]}\end{array}$ \\
\hline
\end{tabular}




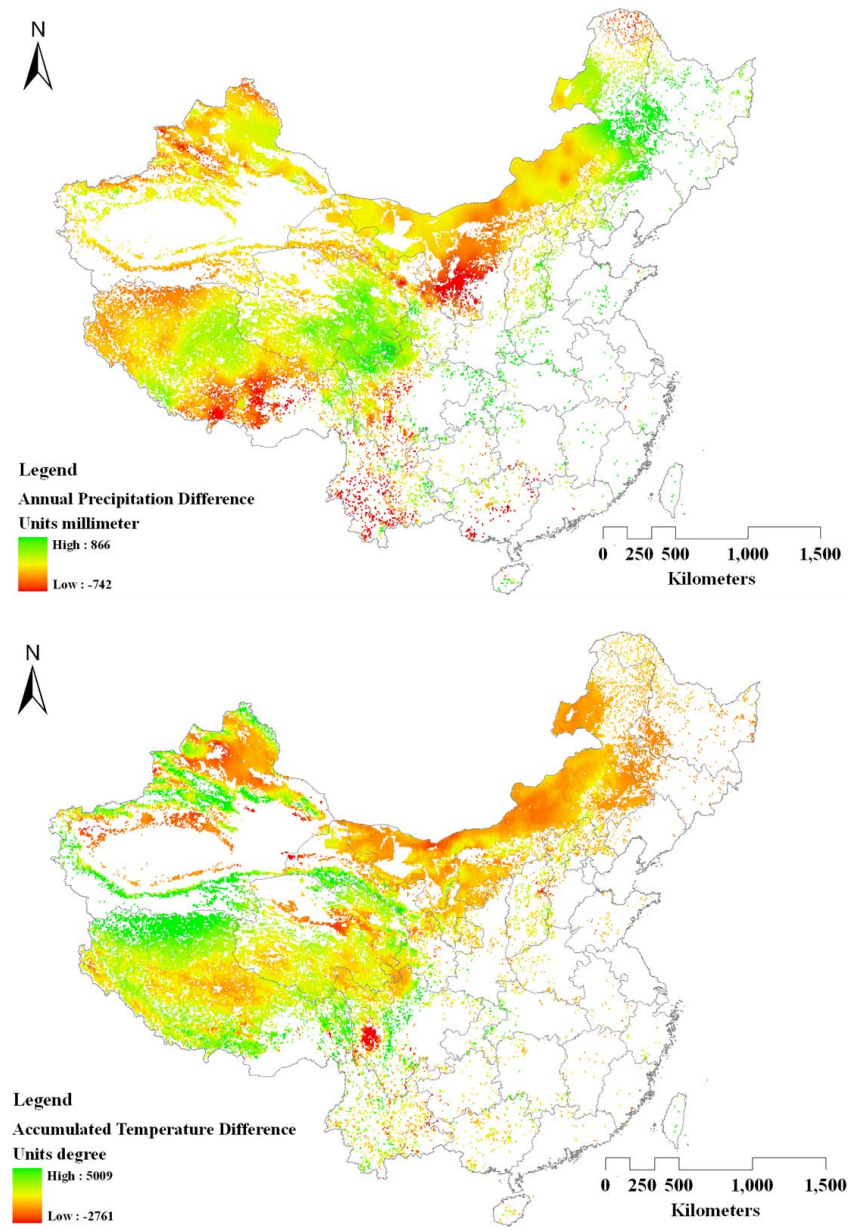

Fig. 7. (a) The annual accumulated precipitation difference between 2005 and 2001. Positive values indicate precipitation increased between 2001 to 2005, and negative values indicate a decrease, (b) The accumulated temperature $>0{ }^{\circ} \mathrm{C}$ difference between 2005 and 2001. Positive values indicate accumulated temperature increased between 2001 to 2005, and negative values indicate a decrease.

modelled $\mathrm{N}_{2} \mathrm{O}$ fluxes were relatively high in these areas. As part of the United Nations Framework Convention on Climate Change, the Chinese Government provided a 1994 national greenhouse gas inventory (China P. R. C., 2004), which was estimated using the IPCC method tier 1 . However, it did not report the direct $\mathrm{N}_{2} \mathrm{O}$ emission from grassland and took only the direct $\mathrm{N}_{2} \mathrm{O}$ emissions from cropland ( $474 \mathrm{Gg} \mathrm{N}_{2} \mathrm{O}-\mathrm{N}$ ) into account. Our estimated grassland $\mathrm{N}_{2} \mathrm{O}$ emission was roughly $1 / 6$ of the $\mathrm{N}_{2} \mathrm{O}$ emission of cropland reported by China P. R. C. (2004) throughout the country. Thus, in the future national $\mathrm{N}_{2} \mathrm{O}$ inventory, the grassland direct $\mathrm{N}_{2} \mathrm{O}$ emissions should be taken into account. Therefore, our work should be a good complement to the national $\mathrm{N}_{2} \mathrm{O}$ inventory. To estimate the reliability of our modelled results and provide readers with a worldwide ranking of Chinese grassland $\mathrm{N}_{2} \mathrm{O}$ emissions, we compared our modelled $\mathrm{N}_{2} \mathrm{O}$ fluxes with those reported for other parts of the world, based on similar grassland types.

\subsubsection{Comparison with North American grasslands}

The temperate grassland in Inner Mongolia is similar to the North Great Plains grassland in the USA. The two grasslands are located at similar latitudes. Mummey et al. (2000) reported $0.24 \mathrm{~kg} \mathrm{Nha}^{-1} \mathrm{y}^{-1}$ emitted from the Great Plains grassland, and Mosier et al. (1996) reported $0.1-0.2 \mathrm{~kg} \mathrm{Nha}^{-1} \mathrm{y}^{-1}$ based on long-term experiments in Colorado. These values were very similar to our $0.26 \mathrm{~kg} \mathrm{~N} \mathrm{ha}^{-1} \mathrm{y}^{-1}$ for temperate grassland in China. For the subalpine meadow experiment site in the USA, values were 0.11 and $0.22 \mathrm{~kg} \mathrm{Nha}^{-1} \mathrm{y}^{-1}$ for 1991 and 1992, respectively (Mosier et al., 1993); for China's similar montane grasslands, this value was $0.14 \mathrm{~kg} \mathrm{Nha}^{-1} \mathrm{y}^{-1}$. The comparisons indicate that the DNDC estimated values were within reasonable ranges.

\subsubsection{Comparison with European and New Zealand grasslands}

About $40 \%$ of the agricultural land in Europe is grassland. Some grasslands are tilled and reseeded to support productive grass species (Pinto et al., 2004). Flechard et al. (2007) reported a mean emission of $0.93 \mathrm{~kg} \mathrm{Nha}^{-1} \mathrm{y}^{-1}$, higher than the $0.26 \mathrm{~kg} \mathrm{Nha}^{-1} \mathrm{y}^{-1}$ we modelled for China's temperate grassland. However, Flechard et al. (2007) pointed out that intensively managed systems emitted more $\mathrm{N}_{2} \mathrm{O}$ than the extensive management grasslands in Europe. Allard et al. (2007) also reported the extensive grassland (similar to natural grassland) had a lower $\mathrm{N}_{2} \mathrm{O}$ emission rate (average $0.13 \mathrm{~kg} \mathrm{~N} \mathrm{ha}^{-1} \mathrm{y}^{-1}$ ) similar to that of China's grasslands.

Fertilizer use is common for European semi-natural grassland as well as grassland in New Zealand that leads to high $\mathrm{N}_{2} \mathrm{O}$ emissions (Boeckx and Van Cleemput, 2001; Saggar et al., 2004, 2007; Levy et al., 2007). However, in China, grasslands are sparsely fertilized or irrigated (Huang et al., 2003; Nan, 2005; Unkovich and Nan, 2008).

\subsubsection{Comparison with African grassland}

Savannahs are the most widespread vegetation in Africa (White, 1983; Rees et al., 2006), and the grass species in savannahs are quite different from those in temperate grasslands (http://www.bcgrasslands.org/library/world.htm). Brummer et al. (2008) found that in an African savannah natural-reserve site (southwest of Burkina Faso), the $\mathrm{N}_{2} \mathrm{O}$ emission rate was 0.52 and $0.67 \mathrm{~kg} \mathrm{Nha}^{-1} \mathrm{y}^{-1}$ in 2005 and 2006, respectively. For Zimbabwean savannah, the measured $\mathrm{N}_{2} \mathrm{O}$ flux was $0.25-0.5 \mathrm{~kg} \mathrm{Nha}^{-1} \mathrm{y}^{-1}$ (Rees et al., 2006). In China, there are no real savannahs as found in Africa, and the most similar vegetation type is Chinese tropical/subtropical grassland. Our estimate for these grasslands 
was $0.38 \mathrm{~kg} \mathrm{Nha}^{-1} \mathrm{y}^{-1}$, within the range of values reported in Africa.

\subsubsection{Global comparison}

Prentice et al. (1993) estimated that the present total area of global grassland is 4.16 billion ha, and China has $8 \%$ of this. If we apply the modelled average $\mathrm{N}_{2} \mathrm{O}$ emission rate $\left(0.22 \mathrm{~kg} \mathrm{Nha}^{-1} \mathrm{y}^{-1}\right)$ based on this ratio, the global grassland $\mathrm{N}_{2} \mathrm{O}$ emission would be $0.92 \mathrm{Tg} \mathrm{Ny}^{-1}$. Globally, the total anthropogenic emission of $\mathrm{N}_{2} \mathrm{O}$ is estimated at 6.36.7 $\mathrm{Tg} \mathrm{Ny}^{-1}$ (Khalil and Rasmussen, 1992; IPCC, 2000). Of that, grassland accounts for $14 \%$ of annual total anthropogenic $\mathrm{N}_{2} \mathrm{O}-\mathrm{N}$ emission. This may underestimate the grassland $\mathrm{N}_{2} \mathrm{O}$ emission contribution to the atmosphere, as most grasslands in China have relatively low emission rates compared to semi-natural grasslands.

In China, grassland has a long history of anthropogenic use, and is currently experiencing serious degradation. Moderating the degradation and improving the grassland conditions are urgent tasks for sustainable development in China. New policies have been proposed to encourage farmers and herdsmen to maintain high productivity of grassland by converting farmland to grasslands or adopting grassland-farming rotation systems (Nan, 2005). Specifically, intensive management practices have been advocated, which can improve the grassland and increase carbon sequestration (Conant et al., 2001), and include fertilizer application and mowing (Committee on Scholarly Communication with the People's Republic of China and National Research Council 1992). However, such practices can also change the $\mathrm{N}_{2} \mathrm{O}$ flux. More research is needed to determine optimal management strategies that achieve a balance between $\mathrm{N}_{2} \mathrm{O}$ emission and carbon-sequestration. The present study was an attempt to apply process-based models such as the DNDC for assessing $\mathrm{N}_{2} \mathrm{O}$ inventory and mitigation potentials on a national scale.

\subsection{Uncertainty analysis}

Great efforts were made in this study to reduce the uncertainties in the estimation of $\mathrm{N}_{2} \mathrm{O}$ inventory, especially in the input data. All input datasets are taken from official statistical data of China and the national survey in order to simulate as precisely as possible. However, there are still uncertainties associated with the climate data, grazing regime and soil data.

Climate is a key parameter of the DNDC model (Fig. 3). In this research, we interpolated precipitation, which produced a larger number of rainfall events with less rainfall per event, but the total precipitation was similar to the observed value. Although there were no significant differences in $\mathrm{N}_{2} \mathrm{O}$ emission between interpolated precipitation and observed precipitation, interpolated data is still a potential source of uncertainty in simulated results (supplement Figs. 1, 2 and 3). In the Qinghai-Tibet plateau, the meteorological stations are very scarce (supplement Fig. 4) and, therefore, the interpolated temperature could be higher than the real value. Higher temperature can increase $\mathrm{N}_{2} \mathrm{O}$ emissions (Fig. 3h), and so cause overestimation of the total $\mathrm{N}_{2} \mathrm{O}$ emissions.

In Chinese natural grassland regions, a rotation grazing method is usually adopted, which requires transferring livestock from one pasture to another in different seasons and staying in the same pasture for the whole season. For example, in the Qinghai-Tibet grassland region, there are three types of pastures: spring-winter, summer, and autumn pasture. In reality, every pasture will be grazed in turn according to the seasons. This grassland management, however, was simplified in this research as we could not find any specific statistical data concerning it. We assumed that livestock stayed in the same pasture for the whole year with $12 \mathrm{~h} \mathrm{~d}^{-1}$ of grazing and at stocking rates that were the same throughout the country. Furthermore, we assumed all grasslands were useable. These assumptions could induce uncertainties in the simulation results. The average stocking density rate may be underestimated, since not all grasslands are usable or are grazed at the same time. This simplified grazing assumption may underestimate $\mathrm{N}_{2} \mathrm{O}$ emissions (Fig. 3d, e). Accurate soil properties can help to reduce uncertainties. In this research, we used the second national soil survey data conducted during 1979-1994 as the initial model input values; it is likely that these values have changed since then. Soil properties were one of the most sensitive factors (Fig. 3b, c), and outdated soil values will increase the uncertainties. Chinese grassland soil is C-neutral and the SOC has increased slightly in the last two decades (Yang et al., 2010), however, this slight SOC increase could cause underestimation of true $\mathrm{N}_{2} \mathrm{O}$ emissions.

\section{Conclusions}

The $\mathrm{N}_{2} \mathrm{O}$ emission rates from various grassland types in China differed. The emissions from temperate, montane, and tropical/subtropical grasslands were $0.26,0.14$ and $0.38 \mathrm{~kg} \mathrm{Nha}^{-1} \mathrm{y}^{-1}$, respectively. Of the 337 million ha of grasslands in China, the annual $\mathrm{N}_{2} \mathrm{O}$ emission was $76.5 \pm 12.8 \mathrm{Gg} \mathrm{N}$. The $\mathrm{N}_{2} \mathrm{O}$ emissions from the entire grassland ecosystems varied year-by-year and increased during 2000-2007, with climate change playing an important role in this process. Grasslands in China have recently been intensively developed and, thus, future emission estimates from grasslands may need to account for more specific grassland management practices, land use change, spatially distributed grazing rates and fertilizer application rates.

\section{Supplementary material related to this article is available online at: http://www.biogeosciences.net/7/2039/2010/ bg-7-2039-2010-supplement.pdf.}


Acknowledgements. This research was funded by "973" Program (2007CB106804); MAIRS and China projects, which was funded by the NASA (NNX08AH50G, NNG05GD49G) and by NSF (BCS-0624018). Additional supports were provided by MAES project funded through the Department of Geography at Michigan State University, "111" Program and Innovative Team Program of Ministry of Education.

Edited by: G. Wohlfahrt

\section{References}

Allard, V., Soussana, J. F., Falcimagne, R., Berbigier, P., Bonnefond, J. M., Ceschia, E., D’Hour, P., C., H., Laville, P., Martin, C., and Pinares-Patino, P.-P.: The role of grazing management for the net biome productivity and greenhouse gas budget $\left(\mathrm{CO}_{2}\right.$, $\mathrm{N}_{2} \mathrm{O}$ and $\mathrm{CH}_{4}$ ) of semi-natural grassland, Agric. Ecosyst. Environ., 121, 47-58, 2007.

Babu, Y., Li, C., Frolking, S., Nayak, D., and Adhya, T.: Field Validation of DNDC Model for Methane and Nitrous Oxide Emissions from Rice-based Production Systems of India, Nutr. Cycl. Agroecosys, 74, 157-174, 2006.

Barnsley, M. J.: Environmental Modeling: A Practical Introduction, Taylor \& Francis, Inc, 2007.

Beheydt, D., Boeckx, P., Sleutel, S., Li, C., and Van Cleemput, O.: Validation of DNDC for 22 long-term $\mathrm{N}_{2} \mathrm{O}$ field emission measurements, Atmos. Environ., 41, 6196-6211, 2007.

Boeckx, P. and Van Cleemput, O.: Estimates of $\mathrm{N}_{2} \mathrm{O}$ and $\mathrm{CH}_{4}$ fluxes from agricultural lands in various regions in Europe, Nutr. Cycl. Agroecosys, 60, 35-47, 2001.

Bouwman, A. F., Taylor, J. A., and Kroeze, C.: Testing hypotheses on global emissions of nitrous oxide using atmospheric models, Chemosphere Global Change Sci., 2, 475-492, 2000.

Brummer, C., Bruggemann, N., Butterbach-Bahl, K., Falk, U., Szarzynski, J., Vielhauer, K., Wassmann, R., and Papen, H.: Soil-atmosphere exchange of $\mathrm{N}_{2} \mathrm{O}$ and $\mathrm{NO}$ in near-natural savanna and agricultural land in Burkina Faso (W. Africa), Ecosystems, 11, 582-600, doi:10.1007/s10021-008-9144-1, 2008.

Chapuis-Lardy, L., Wrage, N., Metay, A., Chotte, J.-L., and Bernoux, M.: Soils, a sink for $\mathrm{N}_{2} \mathrm{O}$ ? A review, Global. Change. Biol., 13, 1-17, doi:10.1111/j.1365-2486.2006.01280.x, 2007.

Chen, B., and Chen, G. Q.: Resource analysis of the Chinese society 1980-2002 based on exergy-Part 4: Fishery and rangeland, Energ. Policy, 35, 2079-2086, 2007.

Chen, D., Li, Y., Grace, P., and Mosier, A.: $\mathrm{N}_{2} \mathrm{O}$ emissions from agricultural lands: a synthesis of simulation approaches, Plant Soil, 309, 169-189, 2008.

Chen, G. X., Huang, B., Xu, H., Zhang, Y., Huang, G. H., Yu, K. W., Hou, A. X., Du, R., Han, S. J., and VanCleemput, O.: Nitrous oxide emissions from terrestrial ecosystems in China, Chemosphere Global Change Sci., 2, 373-378, 2000.

China, P. R. C.: Initial National Communication on Climate Change by the People's Republic of China, Beijing, 34-43, 2004.China Metrological Administration: Climatological Atlas of The People's Republic of China, China Meteorological Press, Beijing, 2002.

Cicerone, R. J.: Analysis of Sources and Sinks of Atmospheric Nitrous Oxide $\left(\mathrm{N}_{2} \mathrm{O}\right)$, J. Geophys. Res. Atmos., 94, 18265-18271, 1989.
Commission for Integrated Survey of Natural Resources, C. A. o. S.: Atlas of Grassland Resources of China (1:1 million), Chinese Academy of Science, Beijing, 10-75 pp., 1995.

Conant, R. T., Paustian, K., and Elliott, E. T.: Grassland management and conversion into grassland: Effects on soil carbon, Ecol. Appl., 11, 343-355, 2001.

Council, C. o. S. C. w. t. P. s. R. o. C. N. R.: Grasslands and Grassland Sciences in Northern China : A Report of the Committee On Scholarly Communication With the People's Republic of China, National Academies Press, Washington, D.C., 1992.

Coupland, R. T.: Natural Grasslands: Introduction and Western Hemisphere, Ecosystems of the World, edited by: Coupland, R. T., Elsevier, New York, 1992.

Dong, Y. S., Zhang, S., Qi, Y. C., Chen, Z. Z., and Geng, Y. B.: Fluxes of $\mathrm{CO}_{2}, \mathrm{~N}_{2} \mathrm{O}$ and $\mathrm{CH}_{4}$ from a typical temperate grassland in Inner Mongolia and its daily variation, Chin. Sci. Bull., 45, 1590-1594, 2000.

Du, R., Chen, G., Lu, D., and Wang, G.: The Primary Research on in situ Measurements of $\mathrm{N}_{2} \mathrm{O}$ and $\mathrm{CH}_{4}$ Fluxes from the Inner Mongolia Grassland Ecosystem, Climatic and Environmental Research, 2, 264-272, 1997.

Du, R., Lu, D., and Wang, G.: Diurnal, seasonal, and inter-annual variations of $\mathrm{N}_{2} \mathrm{O}$ fluxes from native semi-arid grassland soils of inner Mongolia, Soil Biol. Biochem., 38, 3474-3482, 2006.

Du, Y., Cui, Y., Xu, X., Liang, D., Long, R., and Cao, G.: Nitrous oxide emissions from two alpine meadows in the QinghaiTibetan Plateau, Plant Soil, 311, 245-254, 2008.

Fan, J., Zhong, H., Harris, W., Yu, G., Wang, S., Hu, Z., and Yue, Y.: Carbon storage in the grasslands of China based on field measurements of above- and below-ground biomass, Clim. Change, 86, 375-396, 2008.

Fang, J., Liu, G., and Xu, S.: Carbon pools in terrestrial ecosystems in China, edited by: Wang, R. S., Fang, J. Y., Gao, L., Feng, Z. W., Hot spots in modern ecology, China Sciences and Technology, Beijing, 1996.

Flechard, C. R., Ambus, P., Skiba, U., Rees, R. M., Hensen, A., van Amstel, A., Dasselaar, A. v. d. P.-v., Soussana, J. F., Jones, M., Clifton-Brown, J., Raschi, A., Horvath, L., Neftel, A., Jocher, M., Ammann, C., Leifeld, J., Fuhrer, J., Calanca, P., Thalman, E., Pilegaard, K., Di Marco, C., Campbell, C., Nemitz, E., Hargreaves, K. J., Levy, P. E., Ball, B. C., Jones, S. K., van de Bulk, W. C. M., Groot, T., Blom, M., Domingues, R., Kasper, G., Allard, V., Ceschia, E., Cellier, P., Laville, P., Henault, C., Bizouard, F., Abdalla, M., Williams, M., Baronti, S., Berretti, F., and Grosz, B.: Effects of climate and management intensity on nitrous oxide emissions in grassland systems across Europe, Agric. Ecosyst. Environ., 121, 135-152, 2007.

Frolking, S. E., Mosier, A. R., Ojima, D. S., Li, C., Parton, W. J., Potter, C. S., Priesack, E., Stenger, R., Haberbosch, C., Dörsch, P., Flessa, H., and Smith, K. A.: Comparison of $\mathrm{N}_{2} \mathrm{O}$ emissions from soils at three temperate agricultural sites: simulations of year-round measurements by four models, Nutr. Cycl. Agroecosys, 52, 77-105, 1998.

Guo, J. and Zhou, C.: Greenhouse gas emissions and mitigation measures in Chinese agroecosystems, Agr. Forest. Meteorol., 142, 270-277, 2007.

Huang, B., Chen, G., Huang, G., and Hauro, T.: Nitrous oxide emission from temperate meadow grassland and emission estimation for temperate grassland of China, Nutr. Cycl. Agroecosys, 67, 
31-36, 2003.

IPCC: Emissions Scenarios, A Special Report of IPCC Working Group III, Intergovernmental Panel on Climate Change, 3-20, 2000.

IPCC: Climate change 2007: synthesis report,IPCC Fourth Assessment Report, Intergovernmental Panel on Climate Change, 3040, 2007.

Kang, L., Han, X., Zhang, Z., and Sun, O. J.: Grassland ecosystems in China: review of current knowledge and research advancement, Philos. T. R. Soc. B, 362, 997-1008, 2007.

Khalil, M. A. K. and Rasmussen, R. A.: The Global Sources of Nitrous-Oxide, J. Geophys. Res. Atmos., 97, 14651-14660, 1992.

Levy, P. E., Mobbs, D. C., Jones, S. K., Milne, R., Campbell, C., and Sutton, M. A.: Simulation of fluxes of greenhouse gases from European grasslands using the DNDC model, Agric. Ecosyst. Environ., 121, 186-192, 2007.

Li, C., Zhuang, Y., Cao, M., Crill, P., Dai, Z., Frolking, S., Moore, B., Salas, W., Song, W., and Wang, X.: Comparing a processbased agro-ecosystem model to the IPCC methodology for developing a national inventory of $\mathrm{N}_{2} \mathrm{O}$ emissions from arable lands in China, Nutr. Cycl. Agroecosys, 60, 159-175, 2001.

Li, C., Cui, J., Sun, G., and Trettin, C.: Modeling Impacts of Management on Carbon Sequestration and Trace Gas Emissions in Forested Wetland Ecosystems, Environ. Manage., 33, S176S186, 2004.

Li, C.: Quantifying greenhouse gas emissions from soils : Scientific basis and modeling approach $(<$ Special Section $>$ Greenhouse Gas Emissions from Agroecosystems in Monsoon Asia), Soil Sci. Plant Nutr., 53, 344-352, 2007.

Li, C. S.: A model of nitrous-oxide evolution from soil driven by rainfall events .1. model structure and sensitivity, J. Geophys. Res. Atmos., 97, 9759-9776, 1992a.

Li, C. S.: A model of nitrous-oxide evolution from soil driven by rainfall events. 2. model applications, J. Geophys. Res. Atmos., 97, 9777-9783, 1992b.

Li, C. S.: Modeling Trace Gas Emissions from Agricultural Ecosystems, Nutr. Cycl. Agroecosys, 58, 259-276, 2000.

Li, C. S., Aber, J., Stange, F., Butterbach-Bahl, K., and Papen, H.: A process-oriented model of $\mathrm{N}_{2} \mathrm{O}$ and $\mathrm{NO}$ emissions from forest soils: 1. Model development, J. Geophys. Res. Atmos., 105, 4369-4384, 2000.

Li, C. S., Frolking, S., Xiao, X. M., Moore, B., III, Boles, S., Qiu, J., Huang, Y., Salas, W., and Sass, R.: Modeling impacts of farming management alternatives on $\mathrm{CO}_{2}, \mathrm{CH}_{4}$, and $\mathrm{N}_{2} \mathrm{O}$ emissions: a case study for water management of rice agriculture of China, Global. Biogeochem. Cy, 19, GB3010, doi:10.1029/2004GB002341, 2005.

Lin, G. C. S. and Ho, S. P. S.: China's land resources and land-use change: insights from the 1996 land survey, Land Use Policy, 20, 87-107, 2003.

Liu, J.: Integrated Ecosystem Assessment of Western China, Millennium Ecosystem Assessment, Institute of Geographical Sciences and Natural Resources Research, CAS;Research Institute of Forest Resource Information Techniques, CAF; Information Center, SEPA;Research Center for Eco-Environmental Sciences, CAS;Xishuangbanna Tropical Botanical Garden, CAS; Institute of Mountain Hazards and Environment, CAS; Xinjiang Institute of Ecology and Geography, CAS; Cold and Arid Regions
Environmental and Engineering Research, CAS; National Institute for Environmental Studies of Japan., 52, 2001.

Mosier, A. R., Klemedtsson, L. K., Sommerfeld, R. A., and Musselman, R. C.: Methane and nitrous-oxide flux in a Wyoming sub-alpine meadow, Global. Biogeochem. Cy, 7, 771-784, 1993.

Mosier, A. R., Parton, W. J., Valentine, D. W., Ojima, D. S., Schimel, D. S., and Delgado, J. A.: $\mathrm{CH}_{4}$ and $\mathrm{N}_{2} \mathrm{O}$ Fluxes in the Colorado Shortgrass Steppe: 1. Impact of Landscape and Nitrogen Addition, Global. Biogeochem. Cy, 10, 387-399, 1996.

Mummey, D. L., Smith, J. L., and Bluhm, G.: Estimation of Nitrous Oxide Emissions from US Grasslands, Environ. Manage., 25, 169-175, 2000.

Nan, Z.: The grassland farming system and sustainable agricultural development in China, Grassland Science, 51, 15-19, 2005.

National Soil Survey Office: Soil species of China, China Agricultural Press, Beijing, 1993.

National Soil Survey Office: Soil species of China, China Agricultural Press, Beijing, 1994a.

National Soil Survey Office: Soil species of China, China Agricultural Press, Beijing, 1994b.

National Soil Survey Office: Soil species of China, China Agricultural Press, Beijing, 1995a.

National Soil Survey Office: Soil species of China, China Agricultural Press, Beijing, 1995b.

National Soil Survey Office: Soil species of China, China Agricultural Press, Beijing, 1996.

Ni, J.: Carbon Storage in Terrestrial Ecosystems of China: Estimates at Different Spatial Resolutions and Their Responses to Climate Change, Clim. Change, 49, 339-358, 2001.

$\mathrm{Ni}$, J.: Carbon storage in grasslands of China, J. Arid Environ., 50, 205-218, 2002.

Pei, Z., Ouyang, H., Zhou, C., and Xu, X.: Fluxes of $\mathrm{CO}_{2}, \mathrm{CH}_{4}$ and $\mathrm{N}_{2} \mathrm{O}$ from alpine grassland in the Tibetan Plateau, J. Geog. Sci., 13, 27-34, 2003.

Pei, Z. Y., Ouyang, H., Zhou, C. P., and Xu, X. L.: $\mathrm{N}_{2} \mathrm{O}$ exchange within a soil and atmosphere profile in alpine grasslands on the Qinghai-Xizang Plateau, Acta Bot. Sin., 46, 20-28, 2004.

Pinto, M., Merino, P., del Prado, A., Estavillo, J. M., Yamulki, S., Gebauer, G., Piertzak, S., Lauf, J., and Oenema, O.: Increased emissions of nitric oxide and nitrous oxide following tillage of a perennial pasture, Nutr. Cycl. Agroecosys, 70, 13-22, 2004.

Prentice, I. C., Sykes, M. T., Lautenschlager, M., Harrison, S. P., Denissenko, O., and Bartlein, P. J.: Modelling Global Vegetation Patterns and Terrestrial Carbon Storage at the Last Glacial Maximum, Global. Ecol. Biogeogr., 3, 67-76, 1993.

Rees, R. M., Wuta, M., Furley, P. A., and Li, C. S.: Nitrous oxide fluxes from savanna (miombo) woodlands in Zimbabwe, J. Biogeogr., 33, 424-437, doi:10.1111/j.1365-2699.2005.01423.x, 2006.

Saggar, S., Andrew, R. M., Tate, K. R., Hedley, C. B., Rodda, N. J., and Townsend, J. A.: Modelling nitrous oxide emissions from dairy-grazed pastures, Nutr. Cycl. Agroecosys, 68, 243255, 2004.

Saggar, S., Giltrap, D. L., Li, C., and Tate, K. R.: Modelling nitrous oxide emissions from grazed grasslands in New Zealand, Agric. Ecosyst. Environ., 119, 205-216, 2007.

Scurlock, J. M. O., and Hall, D. O.: The global carbon sink: a grassland perspective, Global. Change. Biol., 4, 229-233, doi:10.1046/j.1365-2486.1998.00151.x, 1998. 
Shi, X. Z., Yu, D. S., Warner, E. D., Pan, X. Z., Petersen, G. W., Gong, Z. G., and Weindorf, D. C.: Soil database of 1:1,000,000 digital soil survey and reference system of the Chinese Genetic Soil Classification System, Soil Survey Horizons, 45, 129-136, 2004.

Smith, P., Smith, J. U., Powlson, D. S., McGill, W. B., Arah, J. R. M., Chertov, O. G., Coleman, K., Franko, U., Frolking, S., Jenkinson, D. S., Jensen, L. S., Kelly, R. H., Klein-Gunnewiek, H., Komarov, A. S., Li, C., Molina, J. A. E., Mueller, T., Parton, W. J., Thornley, J. H. M., and Whitmore, A. P.: A comparison of the performance of nine soil organic matter models using datasets from seven long-term experiments, Geoderma, 81, 153225, doi:10.1016/s0016-7061(97)00087-6, 1997.

Unkovich, M. and Nan, Z.: Problems and prospects of grassland agroecosystems in western China, Agric. Ecosyst. Environ., 124, $1-2,2008$.

Wang, Y., Ma, X., Ji, B., Du, R., Chen, Z., Wang, G., Wang, Y., and Wan, $X$.: Diurnal and seasonal variation in methane and nitrous oxide fluxes in meadow steppe of Inner Mongolia, Zhiwu Shengtai Xuebao, 27, 792-796, 2003.
White, F.: The Vegetation of Africa: a descriptive Memoir to accompany the Unesco/AETFAT/UNSO Vegetation Map of Africa, 356, United Nations Educational, Scientific and Cultural Organization (UNESCO), Paris, 356 pp., 1983.

$\mathrm{Xu}$, R., Wang, M., and Wang, Y.: Using a modified DNDC model to estimate $\mathrm{N}_{2} \mathrm{O}$ fluxes from semi-arid grassland in China, Soil Biol. Biochem., 35, 615-620, 2003.

Yamulki, S., Harrison, R. M., Goulding, K. W. T., and Webster, C. P.: $\mathrm{N}_{2} \mathrm{O}, \mathrm{NO}$ and $\mathrm{NO}_{2}$ fluxes from a grassland: Effect of soil $\mathrm{pH}$, Soil Biol. Biochem., 29, 1199-1208, 1997.

Yang, D.: Degradation and protection of grassland on the QinghaiTibet Plateau, Erosion, debris flow and environment in mountain regions. Proceedings of the Chengdu Symposium, China, 1992.

Yang, Y., Fang, J., Ma, W., Smith, P., Mohammat, A., Wang, S., and Wang, W.: Soil carbon stock and its changes in northern China's grasslands from 1980s to 2000s, Global. Change. Biol., doi:10.1111/j.1365-2486.2009.02123.x, 2010.

Yu, D. S., Shi, X. Z., Wang, H. J., Sun, W. X., Chen, J. M., Liu, Q. H., and Zhao, Y. C.: Regional patterns of soil organic carbon stocks in China, J. Environ. Manage., 85, 680-689, 2007. 